Revista Brasil. Bot., V.31, n.3, p.549-553, jul.-set. 2008

Coluna opinião/Point of view

\title{
Cypsela or achene? Refining terminology by considering anatomical and historical factors
}

\author{
JULIANA MARZINEK ${ }^{1}$, ORLANDO CAVALARI DE-PAULA ${ }^{2}$ and \\ DENISE MARIA TROMBERT OLIVEIRA ${ }^{3,4}$
}

(received: July 05, 2007; accepted: June 05, 2008)

\begin{abstract}
Cypsela or achene? Refining terminology by considering anatomical and historical factors). The worry about the indiscriminate use of the terms cypsela and achene for the fruits of Asteraceae has been frequently detached by specialists in this family. The present work was developed aiming to verify the existence of arguments to justify the adoption of a term against the other. After historical and anatomical analysis, we concluded that there is technical basis to consider cypsela and achene as different types of fruits. For Asteraceae, the correct is to call cypsela; achenes are only derived from superior ovaries, as in Plumbaginaceae.
\end{abstract}

Key words - Achene, asteraceae, cypsela, fruit

RESUMO - (Cipsela ou aquênio? Delimitação terminológica considerando aspectos anatômicos e históricos). A preocupação com o uso indiscriminado dos termos cipsela e aquênio para os frutos de Asteraceae tem sido freqüentemente destacada por especialistas na família. O presente trabalho foi desenvolvido com o intuito de verificar a existência de argumentos para justificar a adoção de um termo em detrimento do outro. Após análise histórica e anatômica, concluiu-se que há fundamento técnico para considerar cipsela e aquênio como diferentes tipos de frutos. Para Asteraceae, o correto é denominar cipsela, já que aquênios são formados somente a partir de ovários súperos, como em Plumbaginaceae.

Palavras-chave - Aquênio, asteraceae, cipsela, fruto

Precise structural analyses are essential to the precise descriptions and comparisons among taxa. The larger and more complex groups have the biggest problems related to the multiplicity and inadequacy of the terminology available. The fruits of Asteraceae are very distinct from fuits of other families but present great morphological similarity among species. However, the names given to the fruits within the family are variable and include, apparently indiscriminately, the terms achene (from the Greek $a$ - + chaino, not opened, according to Spjut 1994) and cypsela (from the Greek kypselé, a box, according to Spjut 1994).

This text presents a historical view of the use of the terms achene and cypsela and proposes to standardize

1. Universidade Estadual Paulista, Instituto de Biociências, Departamento de Botânica, Caixa Postal 510, 18618-000 Botucatu, SP, Brazil.

2. Universidade Estadual Paulista, Instituto de Biociências, Departamento de Botânica, Avenida 24A, Bela Vista, 13506-900 Rio Claro, SP, Brazil.

3. Universidade Federal de Minas Gerais, Instituto de Ciências Biológicas, Departamento de Botânica, Av. Antônio Carlos, 6627, Pampulha, Caixa Postal 486, 31270-901 Belo Horizonte, MG, Brazil.

4._Autor para correspondência: dmtoliveira@ icb.ufmg.br the terms used to differentiate the fruits of Asteraceae and those families with related structures based on anatomical criteria.

The need of a touchstone for botanical terms has been discussed during the last several meetings of Sociedade Botânica de São Paulo and Sociedade Botânica do Brasil. In particular, discussions were initiated during reunions with specialists in the Asteraceae concerning the adoption of either the term achene or cypsela for the fruits of this family, and the need to precisely define the terms and standardize their use.

An initially analysis of the literature indicated that Richard (1808) apud Roth (1977) applied the term achene to the fruits of Rhamnales and Rosaceae (Rosales sensu APG 2003), as well as to the special types of fruits of the Umbelliferae (Apiaceae sensu APG 2003), Labiatae (Lamiaceae), and Compositae (Asteraceae).

As we could investigate, Mirbel (1813) used at first time the term cypsela for the Asteraceae fruits. The author defined cypsela as a monospermic fruit that is crowned by the calyx, in other words formed by inferior ovary. Mirbel detached that cypselae are unilocular and the unique seed is not attached to the pericarp. 
The first work that use both terms, achene and cypsela, was Beck (1891), that considered achenes exclusively as a dry indehiscent fruit originating from the apocarpic gynoecium. Beck named cypselae the fruits of Asteraceae.

Following these initial publications, however, the two terms came to be used indiscriminately, practically as synonyms. Some authors chose to use the term cypsela, such as Fahn (1974) and Bremer (1994), while others employed the term achene, such as Wagenitz (1976) and Souza (2006) without, however, ever discussing the distinctions between them.

Chute (1930) classified achenes as small, dry, indehiscent fruits, with their seeds not adhering to the carpel, exemplified by the sunflower. In that work, the author considered the achene as being derived from the follicle, having similar vasculature.

According to Angely (1959), the achene is "any dry, indehiscent, apocarpic, simple, unilocular, monospermic fruit, whose pericarp does not strongly adhere to the seed coat (the seed joins to the pericarp at the point of insertion of the placenta); often some floral parts, such as the calyx, persist".

Eames (1977) restricted his consideration to the term achene, noting that it was a monospermic indehiscent fruit, originating from two or more carpels, as in the families Asteraceae and Typhaceae; this author pointed out the possibility of the term being applied to fruits with two seeds, but did not mention the position of the ovary.

In a general treatment of fruit anatomy, Roth (1977) only mentioned the achene, defining it as a special form of dry indehiscent fruit characteristic of the Asteraceae in which seed coat and fruit wall are tightly attached to each other, but frequently not completely coalesced. The classification of this fruit type is difficult, however, because detailed studies of the degree of adnation between the pericarp and testa are relatively rare. According to this author, the concept of achene became still more confused when some Anglo-Saxon authors began to include within the same category the dry indehiscent follicles of Ranales and Rosaceae (Rosales sensu APG 2003), as well as other families in which the pericarp appears to adnate to the seed coat. This author also noted that in German-language countries the fruits of Asteraceae are understood as achenes.

To Font Quer (1985), achenes are dry, monospermic, indehiscent fruits, with the pericarp independent of the seed (not fused to it). This author stated that the term was coined by Richard (1808) apud Roth (1977) for fruits that had previously been confused with seeds. According to the definition offered by Palau (1788 apud Font Quer 1985), the oak fruits (acorns) and hazelnuts are achenes, as well as the fruits of the Ranunculaceae, Umbelliferae, Labiatae and Compositae, among others. Font Quer (1985) pointed out that Beck (1891) proposed a more rational classification for fruits, describing cypselae as achenes derived from an inferior ovary and from more than one carpel, as seen in the Dipsacaceae and Compositae. Roth (1977) likewise attributed the term cypsela to Beck (l.c.), demonstrating that the work of Mirbel (1813) had been forgotten by science.

Mauseth (1988) considered achenes as dry, indehiscent, small and simple fruits containing only a single seed. The fruit wall is usually quite thin and papery, and the seed is loose inside, as in the sunflower. Nonetheless, the term cypsela is cited by the author as being a fruit very similar to the achene, except that, because it develops from an inferior ovary, it contains extra tissues around the true pericarp, as seen in the dandelion. This author also distinguished between these two types of fruit based on the number of carpels that produced them: only one carpel in an achene and multiple carpels in a cypsela. It is interesting to note that the author gives examples of both types of fruits using species of Asteraceae.

The term achene was also used by Weberling (1992), who considered the occurrence of two special types of indehiscent fruits, the achene and the caryopsis, the latter being fruits in which the coat of the single seed is fused with the pericarp during ripening.

According to Spjut (1994), cypselae differ from achenes by the presence of an extra layer derived from the perianth and formed over the pericarp as a result of the inferior position of the ovary. As such, the cypselae were included in the Angiocarpi series, which includes fruits with extra-carpel structures adhering to the pericarp. The achenes were included in the Gimnocarpi series, in which the fruits consist mostly of a developed pericarp. Spjut (l.c.) pointed out that many botanists have ignored these distinctions and have continued to use the word achene incorrectly. It is important to point out that Spjut himself (p. 23) erroneously included the fruits of Helianthus annuus (Asteraceae) among the achenes. The absence of any pappus on fruit of this species possibly confused the author, even though the inferior position of the ovary can easily be recognized by the observation of the apical scar of the extra-ovarian floral parts.

Barroso et al. (1999) did not mention the term cypsela. For these authors, the achene is a fruit originating from an inferior and bicarpellate ovary, monospermic, with the central area not divided into locules, with modifications of the calyx into a pilose or aristate pappus, and exemplified only by species of Asteraceae. 
To Harris \& Harris (2001) achene is "a small, dry, indehiscent fruit with a single locule and a single seed (ovule), and with the seed attached to the ovary wall at a single point, as in the sunflower". According to the authors, cypsela is a "dry, single-seeded, indehiscent fruit with an adnate calyx, as in some achenes in the Compositae (Asteraceae)". As well as Mauseth (1988), the authors exemplify both types of fruits using Asteraceae species.

Recently Anderberg et al. (2007) stated that the fruit of Asteraceae "is one-seeded, normally an achene (sometimes but superfluously termed a cypsela), very rarely a drupe, usually regarded as indehiscent but often with preformed dehiscence lines opening by pressure of the germinating embryo".

In light of these historical antecedents, it was deemed necessary to verify anatomical aspects that might support the adoption and use of these terms. To that aim, two plant species with ample distribution in Brazil, and with ovaries in distinct positions, were selected for closer examination. The ovaries and mature fruits of Stifftia chrysantha Mikan (Asteraceae) and Plumbago auriculata Lam. (Plumbaginaceae) were embedded in methacrylate Leica ${ }^{\circledR}$ (according to standard techniques), sectioned and stained for light microscopy examination. Both species are syncarpic, unilocular, with one ovule that forms a single seed that does not adhere to the pericarp. Stifftia chrysantha has inferior ovaries, while $P$. auriculata has superior ovaries.

In median transversal section, the ovaries of $S$. chrysantha demonstrated ten outer receptacle vascular bundles, accompanied by two additional inner and smaller carpel bundles (figure 1). In the mature fruit (figures 2-4) an ample aerenchyma could be seen, formed in the internal layers of the pericarp, and lignification could be seen on the fibers of the receptacle and pericarpial vascular bundles. The seed remains free, not adhering to the pericarp (figures 2-3).

The median transversal sections of $P$. auriculata demonstrated only five carpel vascular bundles (figure 5) arranged in a single circle within the ovarian mesophyll. This species does not show the receptacle tissues observed in $S$. chrysantha. In the mature fruit, the pericarp retains the same organization of the ovarian wall from which it was integrally derived (figures 5-8), remaining free from the seed coat (figure 6).

Based on the anatomical arguments presented, it can be seen that fruits from ovaries in distinct positions generate recognizable structures that can be easily distinguished by an analysis of their pericarpial vasculature. While the walls of superior ovaries produce the entire pericarp and form fruits with a simple origin, inferior ovaries (of both the receptacle, as in S. chrysantha, and the appendicular type) produce complex fruits, that is, fruits where the pericarp is accompanied by tissues of extra-pericarpial origin (derived from the receptacle or from the hypanthium, when the inferior ovaries are appendicular). Observations of the transversal sections of $S$. chrysantha (figures 1-4) demonstrated the regions produced both by the receptacle and by the pericarp stricto sensu, even though there was no fine dividing line visible between them: the region is of extra-carpel origin up until the outer vascular bundles (receptacle bundles, that will gave off traces to the sepals, petals, and stamens); internally, the pericarp s.s. can be seen, originating from the ovary wall inserted into the receptacle, and having only two vascular bundles.

It is worth noting here an important point related to terminology: the definitions of the pericarpial layers according to ontogenetic concept (the outer epidermis of the ovary produces the exocarp, the inner layer forms the endocarp, and the ovarian mesophyll constitutes the mesocarp, which is the vascularized region of the fruit) do not permit the use of the term exocarp to denominate fruit coverings of complex origin. In these cases, it is advisable to adopt a morphological concept (pericarp lato sensu), calling exocarp the outer covering of the fruit, including within mesocarp the tissues that have both carpel and extra-carpel origin (both of which are vascularized).

In light of these considerations, it becomes crucial to recognize that achenes and cypselae are different types of fruits, distinct from their origin. In that perspective, the fruits of the Asteraceae must be considered cypselae, while those of the Plumbaginaceae constitute achenes.

Cypselae then can be defined as complex fruits, dry, indehiscent, unilocular, with a single seed not adnate to the pericarp (linked only by the funicle) and originating from an inferior ovary. Achenes are simple fruits, dry, indehiscent, unilocular, with a single seed linked to the pericarp only by the funicle, originating from superior ovaries. As the basic morphological difference is related to the position of the ovary, a characteristic easily observed even in mature fruits, the discriminate use of the terms cypsela and achene should not generate practical problems and will permit an accurate standardization of the terminology. What is important is that structures that differ in such a fundamental way as the achenes and cypselae should not be treated as synonyms, as if their distinct origins did not justify their division into two clearly defined types. 

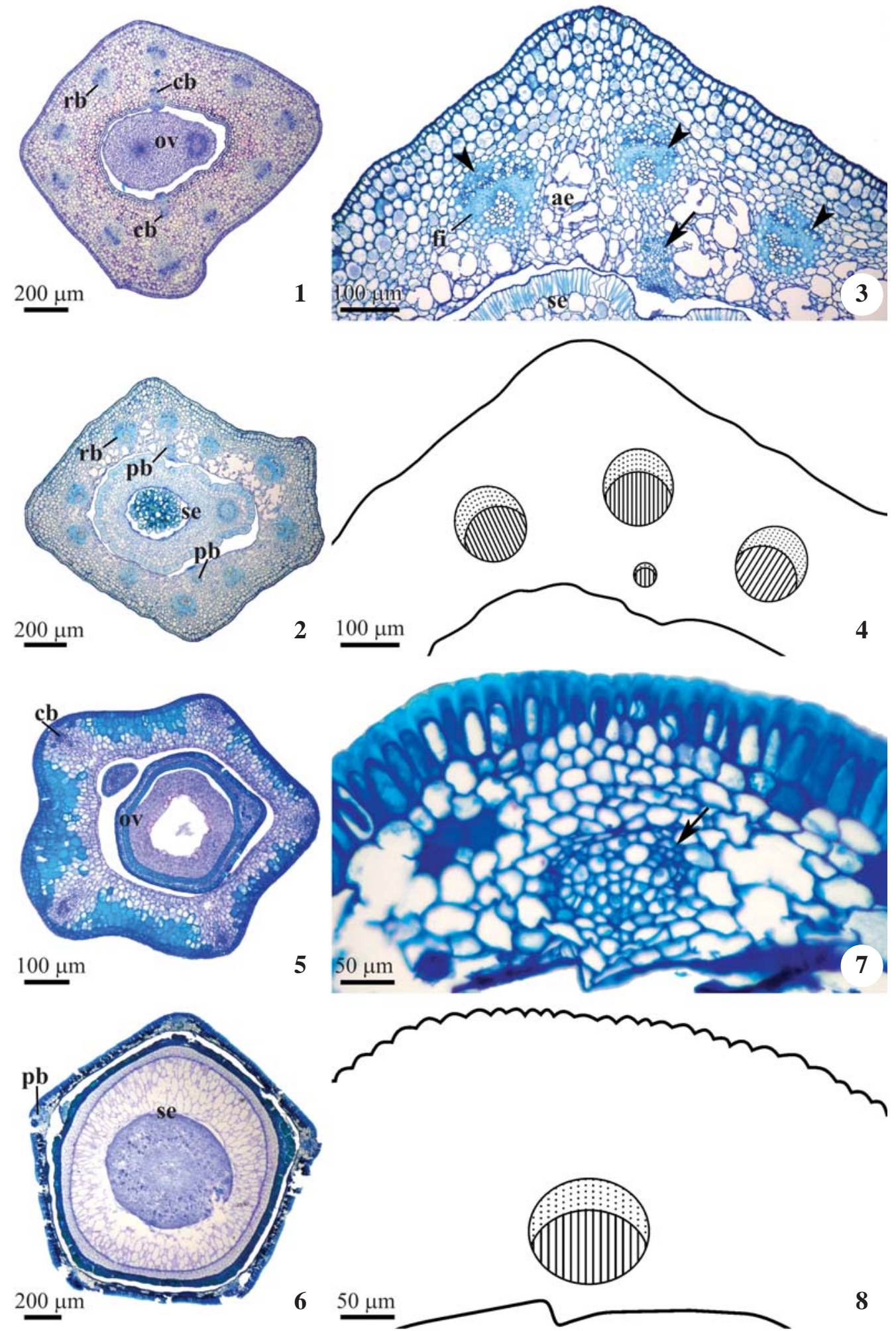

8

Figures 1-8. Transversal sections of the ovaries and fruits of Stifftia chrysantha Mikan (1-4) and Plumbago auriculata Lam. (5-8). 1-2. General aspect of the ovary and fruit, respectively. 3. Detail of fruit, demonstrating receptacle bundles (arrowhead) and pericarp bundle (arrow). 4. Outline drawing of previous figure. 5-6. General view of the ovary and fruit, respectively. 7. Detail of fruit, demonstrating a pericarp bundle (arrow). 8. Outline drawing of previous figure. $(\mathrm{ae}=$ aerenchyma; $\mathrm{cb}=$ carpel bundle; $\mathrm{fi}=$ fiber; ov $=$ ovule; $\mathrm{pb}=$ pericarp bundle; $\mathrm{rb}=$ receptacle bundle; $\mathrm{se}=$ seed; in figures 4 and 8 : dothed lines $=$ phloem; parallel lines $=$ xylem). 
Acknowledgements - The authors thank to Conselho Nacional de Desenvolvimento Científico e Tecnológico (CNPq) for the post-graduate grants of J.Marzinek and O.C. De-Paula and for the research grant of D.M.T. Oliveira, and to Fundação de Amparo à Pesquisa de Minas Gerais (FAPEMIG) for financial support.

\section{References}

ANDERBERG, A.A., BALDWIN, B.G., BAYER, R.G., BREITWIESER, J., JEFFREY, C., DILLON, M.O., ELDENÄS, P., FUNK, V., GARCIA-JACAS, N., HIND, D.J.N., KARIS, P.O., LACK, H.W., NESOM, G., NORDENSTAM, B., OBERPRIELER, C.H., PANERO, J.L., PUTTOCK, C., ROBINSON, H., STUESSY, T.F., SUSANNA, A., URTUBEY, E., VOGT, R., WARD, J. \& WATSON, L.E. 2007. Compositae. In The families and genera of vascular plants (Kubitzki, K., Kadereit, J.W. \& Jeffrey, C., eds.). Springer Verlag, Berlin, p.61-576.

ANGELY, J. 1959. Dicionário de botânica. 2a ed., Phyton, Curitiba.

APG. 2003. An update of the Angiosperm Phylogeny Group classification for the orders on families of flowering plants: APG II. Botanical Journal of the Linnean Society 141:399-436.

BARROSO, G.M., MORIM, M.P., PEIXOTO, A.L. \& ICHASO, L.F. 1999. Frutos e sementes: morfologia aplicada à sistemática de dicotiledôneas. Editora UFV, Viçosa.

BECK, G.R. 1891. Versuch einer neuen classification der früchte. Verhandlung der Zoologischen-Botanischen Gesellschaft, Wien 41:307-312.
BREMER, K. 1994. Asteraceae: cladistics and classification. Timber Press, Portland.

CHUTE, H.M. 1930. The morphology and anatomy of the achene. American Journal of Botany 17:703-722.

EAMES, A.J. 1977. Morphology of the Angiosperms. Robert E. Krieger, New York.

FAHN, A. 1974. Anatomia Vegetal. Traducion F.G. Arenal, J.F. Casas \& J.F. Perez. H. Blume Ediciones, Madrid.

FONT QUER, P. 1985. Diccionario de Botánica. Editorial Labor, Barcelona.

HARRIS, J.G. \& HARRIS, M.W. 2001. Plant identification terminology: an illustrated glossary. $2^{\text {nd }}$ ed., Spring Lake Publishing, Spring Lake.

MAUSETH, J.D. 1988. Plant anatomy. Benjamin Cummings, Menlo Park.

MIRBEL, M. 1813. Nouvelle classification des fruits. Nouveau Bulletin des Sciences 3:313-319.

ROTH, I. 1977. Fruits of Angiosperms. Gebrüder Borntraeger, Berlin.

SOUZA, L.A. 2006. Fruto. In Anatomia do fruto e da semente (L.A. Souza, org.). Editora UEPG, Ponta Grossa, p.11123.

SPJUT, R.W. 1994. A systematic treatment of fruit types. Memoirs of the New York Botanical Garden 70: 1-182.

WAGENITZ, G. 1976. Systematics and phylogeny of the Compositae (Asteraceae). Plant Systematics and Evolution 125:29-46.

WEBERLING, F. 1992. Morphology of flowers and inflorescences. Cambridge University Press, Cambridge. 